\title{
配電用避雷器の雷過電圧抑制効果
}

\begin{tabular}{|c|c|c|c|c|c|c|c|c|c|c|c|c|}
\hline 正 員 & 藤 & 原 & 信 & 行 & （東京電力） & 正 & 員 & 浅 & 川 & & 聡 & (電力中研) \\
\hline 員 & 米 & 山 & & 司 & (東京電力) & 正 & 員 & & 村 & 哲 & 朗 & (三菱電機) \\
\hline 員 & 濱 & 田 & & 之 & （東京軞力） & 正 & 員 & 山 & 岡 & 浩 & 一 & (三菱電機) \\
\hline 非会員 & 棈 & 田 & & 勤 & (電力中研) & 正 & 員 & 石 & 辺 & 信 & 台 & (三菱電機) \\
\hline
\end{tabular}

\section{Lightning Overvoltage Protective Effect of Distribution Line Arresters}

Nobuyuki Fujiwara, Member, Tsukasa Yoneyama, Member, Yoshiyuki Hamada, Member (Tokyo Electric Power Co.), Tsutomu Yokota, Nom-member, Akira Asakawa, Member (Central Research Institute of Electric Power Institute), Tetsuro Shimomura, Member, Koichi Yamaoka, Member, Shinji Ishibe, Member (Mitsubishi Electric Corp.)

The primary aim of surge arresters in power distribution lines is to protect lines and equipment from the voltage induced by nearby lightning strokes. For the further improvement of the power system, protection of distribution lines against direct lightning strokes needs to be investigated. One of the effective measures against direct lightning strokes is to increase the number of arresters. However, if the surge current is too large, some surge arresters absorb a large amount of energy in excess of their capability and may be broken, leading to a line fault. To evaluate the protective effect of the surge arresters against direct lightning strokes to overhead ground wire, the authors measured the voltage across arresters and the energy absorbed by surge arresters using a full scale model line and a $12 \mathrm{MV}$ inpulse generator. The results were compared with simulation results by EMTP. There have been no previous studies making a comparison of this kind.

キーワード : 配電線, 直撃雷, 架空地線, 避雷器, 実験, 解析

\section{1.まえがき}

我が国の配電線雷事故対策は, 誘導雷を主対象として架 空地線の架設や避雷器の設置の対策を推進してきた。雷に よる配電線事故件数はこの10 年間で減少しているが，全 体の事故件数に占める割合は $30 \%$ 前後とまだ高い。直撃 雷が起こった場合，発生頻度は少なくてもほとんどが線路 事故になるため，この高い割合は変わらないだろうとこれ まで考えられてきた。また，瞬時停電が社会に与える影響 が重要な関心事になっており，電力供給の信頼性を更に向 上させるため, 配電用避雷器（以下, 避雷器と呼ぶ）の積 極的な適用が考えられるが，適用にあたっては直撃雷に対 する保護効果とエネルギー責務を評価することが必要であ る。

直撃雷による配電線の応答に関しては，縮小モデルを用 いた計算 ${ }^{(1)(2)} や ，$ 実規模配電線を使った実験的検討 ${ }^{(3)}$ が行 われてきた。また著者らは，実規模配電線モデルを用いた 実験結果(4) と EMTP (Elecro-Magnetic Transients Program) を使った解析の比較を行ったが(5), 避雷器の電圧・
電流は測定されておらず, 避雷器のエネルギー処理量を直 接評価できなかった。

今回, 著者らは架空地線への直撃雷に対する避雷器の過 電圧抑制効果を確認するため，奏規模配電線を用いて実験 を行い避雷器の電圧・電流や避雷器の処理エネルギーを測 定した。本論文では，実験結果と EMTPによる解析結果 を比較して, 直撃雷に対する配電線過電圧や避雷器の処理 エネルギーを解析で精度良く求めることが可能であること を示す。

\section{2. 実験方法}

〈2・1〉実験回路実験は, 電力中央研究所の塩原実 験場の $12 \mathrm{MV}$ インパルス発生装置を用い, 全長 $350 \mathrm{~m} の$ 実規模配電線で実施した。実験場の配置を図 1 に, 実験線 路の構成を図 2 に示す。また装柱状況を図 3 に示す。

実験配電線は, 東京電力の標準的な配電線を模擬してい る。配電線は, $6.6 \mathrm{kV}$ 高圧線, 架空地線 (以下, $\mathrm{GW}$ と 略記), 架空共同地線から構成される。低圧線は省略した。 合計 9 本のコンクリート電柱を約 $40 \mathrm{~m}$ 間隔で図 1 のよう 
に配置し, 電柱 2 本ごとに接地した。配電線のサージイン ピーダンスと整合をとるため，図 2 のように末端の 1 号柱 および 9 号柱で配電線を $400 \Omega$ の抵抗を介して接地した。

〈2.2〉 実験条件 実験条件を表 1 k示す。避雷器の 雷過電圧抑制効果を確認するため, 避雷器の設置場所およ び電柱の接地位置を変えた。また、インパルス電流の印加 点を図 2 の 5 号柱の柱頂，4号柱の柱頂，または 4 号柱と 5 号柱の径間中央の 3 点とした。印加電流恃本試験構成に おけるインパルス発生装置の最大電流に近い $18 \mathrm{kA}$ と, 配電線の中実がいしがフラッシオーバしない電流 $8 \mathrm{kA}$ を 選定した。またインパルス電流の波頭長（峻度）は $2 \mu \mathrm{s}$ を設定し，波尾長は今回の試験構成加ら決まる $11 \mu$ ととし た。

〈2・3〉 測定項目 测定項目は図 2 に示す 5 号柱接地

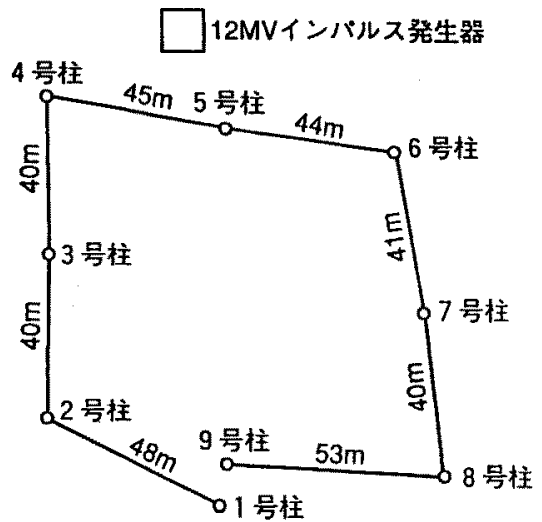

図 1 実験場構成図

Fig. 1. Test field.
表 1 実驗条件

Table 1. Test conditions.

\begin{tabular}{|c|c|c|c|c|}
\hline $5-x$ & $\begin{array}{c}\text { 印加電流 } \\
(\mathrm{k} A)\end{array}$ & 電流印机点 & 接地雷柱 & $\begin{array}{l}\text { 避雷㗊 } \\
\text { 設是渽所 }\end{array}$ \\
\hline$\overline{A-1}$ & \multirow{2}{*}{18} & 4 号柱 & \multirow{2}{*}{$3,5,7$} & \multirow{2}{*}{ 全柱 } \\
\hline$A-3$ & & 5 酸柱 & & \\
\hline$B-1$ & \multirow{3}{*}{8} & 4 昂柱 & \multirow{3}{*}{$3,5,7$} & \multirow{3}{*}{$\begin{array}{l}2 \text { 柱こと } \\
1,3,5,7,9\end{array}$} \\
\hline$B-2$ & & 中間点 & & \\
\hline$B-3$ & & 5 号柱 & & \\
\hline$\overline{c-1}$ & \multirow{3}{*}{8} & 4 朚柱 & \multirow{3}{*}{$3,5,7$} & \multirow{3}{*}{ なし } \\
\hline$c-2$ & & 中闍点 & & \\
\hline$c-3$ & & 5 年柱 & & \\
\hline$\overline{D-3}$ & 18 & 5 号柱 & $2,4,6,8$ & 全柱 \\
\hline
\end{tabular}

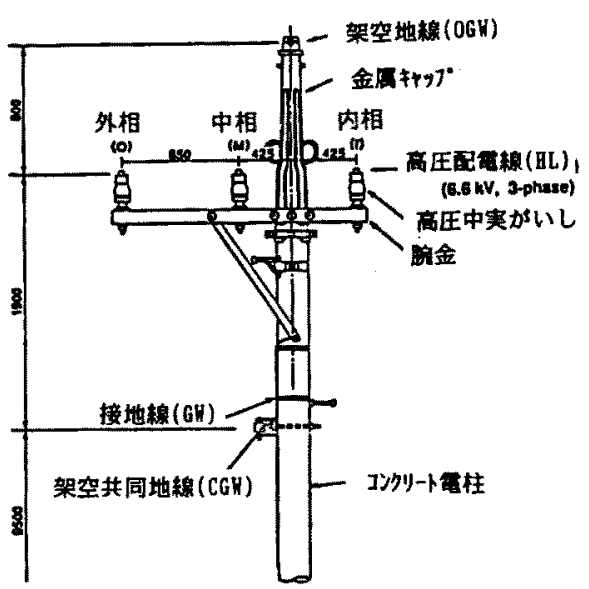

図 3 実験線路装柱

Fig. 3. Experimental pole assembly (unit : $\mathrm{mm}$ )

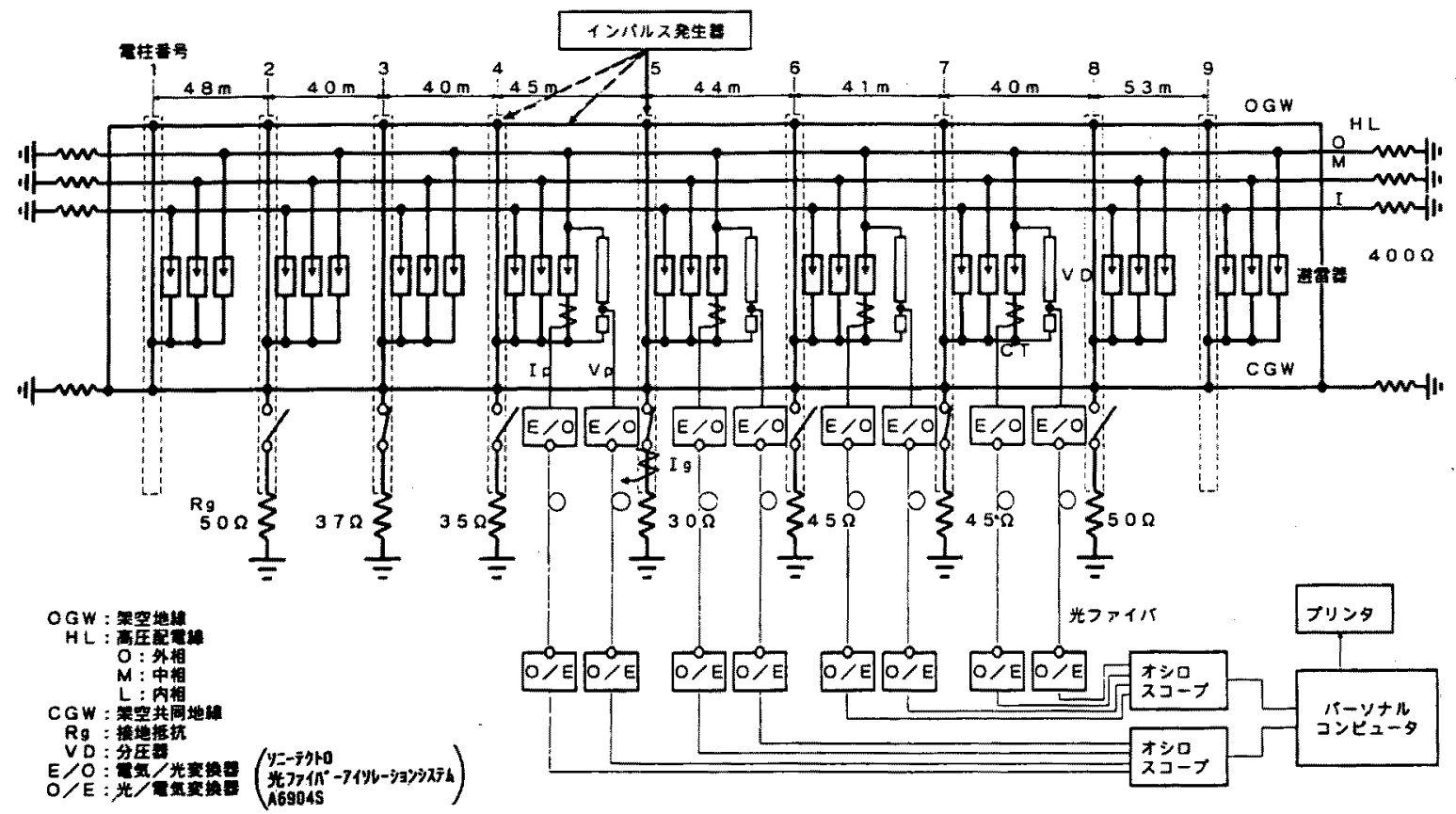

図 2 実験線路構成

Fig. 2. Experimental line configuration. 


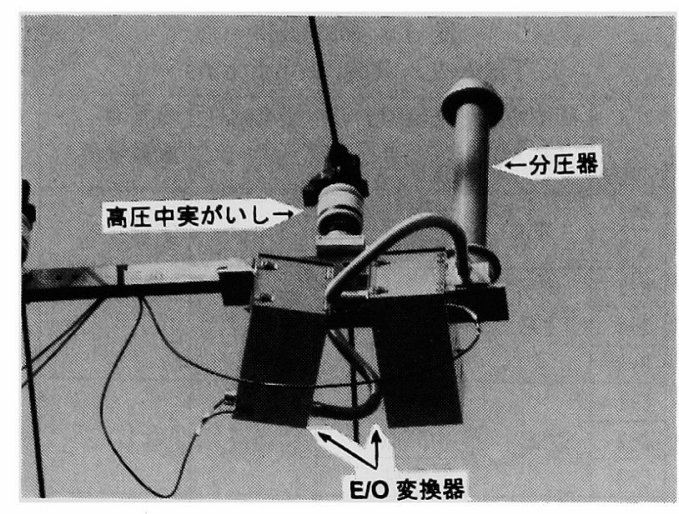

図 4 測定装置

Fig. 4. Measuring instruments.

電流 $\left(I_{g}\right)$, 避雷器動作電流 $\left(I_{p}\right)$, 避雷器端子間電圧または 高圧中実がいし端子間電圧 $\left(V_{p}\right)$ などである。今回，実規 模配電線モデルで避雷器動作電流および避雷器端子間電圧 を測定した。避雷器動作電流 $I_{p}$ は避雷器の下部に CT 避雷器端子間電圧 $V_{p}$ は柱の腕金部に分圧器をそれぞれ設 置して測定し, 腕金部に取り付けた $\mathrm{E} / \mathrm{O}$ 変換器で光信号 に変換して光ファイバで地上にデータを送信し，地上で $\mathrm{O} / \mathrm{E}$ 変換器で電気信号に戻してパーソナルコンピュータ （以下, パソコンと略記）に入力する。分圧器と避雷器ま たは中実がいしの頭部とは約 $60 \mathrm{~cm}$ の耐熱ビニル電線 $\left(5.5 \mathrm{~mm}^{2}\right)$ で接続した。避雷器の処理エネルギーは避雷 器動作電流 $I_{p}$ と避雷器端子間電圧 $V_{p}$ の值を用いてパソ コンで算出した。なお，図 2 では，3，5，7号柱を接地 し，2，4，6，8 号柱は電柱の下部で接地線を開放してお り，表 1 のケース A〜ケース C の接地形態に対応してい る。図 4 に分圧器および $\mathrm{E} / \mathrm{O}$ 変換器を電柱の腕金部に取 り付けた状態を示す。また接地電流は, 架空共同地線と接 地抵抗を接続する接地線に流れる電流と, コンクリート電 柱自体を流れる電流を一括して測定した。

\section{3. 解析モデル}

解析は EMTP を用いて行った。以下にモデルの考え方 を述べる。

〈3・1〉 線路モデル 高圧線, 架空地線, 架空共同地 線の線路定数は, 表 2 の線種デー夕および図 2, 図 3 の電 柱配置データから EMTP の J. Marti セットアップサブプ ログラムを用いて求めた。

〈3・2〉 避雷器モデル＼cjkstart避雷器の電圧一電流特性を, EMTP の非線形抵抗モデルを用いて折れ線近似で表現し た。避雷器の制限電圧は $V_{2.5 \mathrm{kA}}=29.4 \mathrm{kV}$ とした。

〈3・3〉 コンクリート電柱モデル コンクリート電柱 は, 内部に数本の鉄筋が円形に配置されており, 鉄筋と電 柱表面との間隔は $20 \mathrm{~mm}$ である。表 1 のケース D-3で は, 5 号柱は接地されていないにもかかわらず, 図 5 に示 す電流が測定されており, インパルス電流がコンクリート 電柱を通って大地へ流れている。セメントの固有抵抗は平
表 2 線路定数の条件

Table 2. Dimensions of model line.

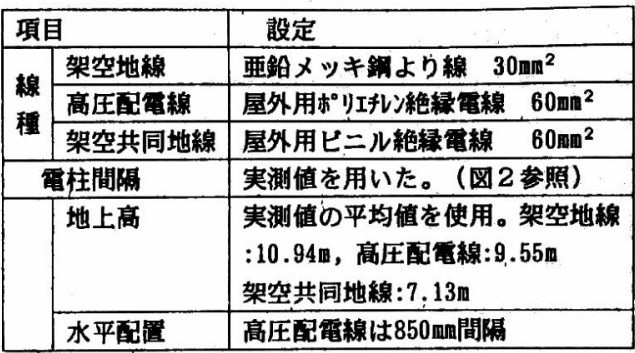

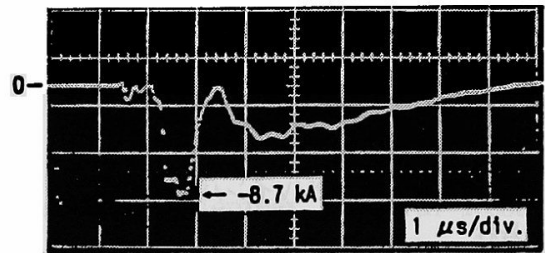

図 5 非接地柱を流れる電流（ケース D-3，5号柱） Fig. 5. Current through ungrounded pole No. 5 in case D-3 impulse current : $18 \mathrm{kA}$.
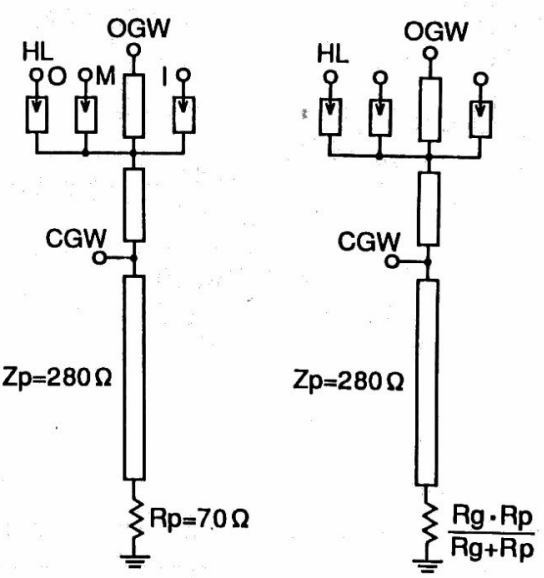

$R p ：$ コンクリート蛋柱の接地効果 $\mathrm{Rg}$ : 接地線の接地抵抗
(a)接地線のない
電柱モテル
(b)接地線がある 電柱モテル

図 6 解析に用いた電柱モデル

Fig. 6. Pole models used in the simulation.

均的に $100 \sim 300 \Omega \cdot \mathrm{m}$ といわれており ${ }^{(6)}$ ，この值を用いる と, 図 3 のキャップと鉄筋の間の抵抗はわずか $10 \sim 30 \Omega$ 前後である。また, コンクリート電柱の表面と鉄筋の間の インパルス耐電圧は $4 \sim 5 \mathrm{kV}$ という報告がある(7)。

これらから, 直撃雷の過電圧解析時には, インパルス電 流に対するコンクリート電柱の導電性を考虑して，電柱を 介した接地効果を考慮したほうがよいと考えられる。配電 設備において，コンクリート電柱のサージインピーダンス を接地線と並列に考慮して実験と解析結果を比較した例が 報告されている(8)。著者らも，同様のモデルを使用すると 
電柱の導電性を考慮しない場合より実測結果に近い解析結 果を得ており，上述のモデルの有効性を確認している ${ }^{(9)}$ 。 今回, 電柱を図 6 に示すモデルで表現した。接地線のな い電柱のサージインピーダンスは, 鉄筋が配置されている 円周の半径 $r$, 鉄筋高さ $h$ を次式に入れて求めた ${ }^{(10)}$ 。

$$
Z_{T}=60[\ln (2 \sqrt{2} h / r)-1]
$$

接地線のある電柱のサージインピーダンスは, 接地線と鉄 筋が接近しており接地線が細いため, 接地線がない電柱の サージインピーダンスと変わらないと考えた。電柱の接地 抵抗 $R_{p}=70 \Omega$ は, EMTP による解析值が図 5 の電流值 と一致するように設定した。

\section{4. 実測と解析の比較}

\section{〈4・1〉 各ケースにおける比較}

（1）避雷器全柱設置の場合 ケース A-1について 実測と解析波形の比較を表 3 に示す。解析ではコンクリー
ト電柱のインパルスに対する導電性考慮の有無の影響につ いて検討した。導電性を考慮しない場合, 接地線サージイ ンピーダンスは $500 \Omega$ とした。電柱の導電性を考慮しない と電流波形が大きく異なる。これに対して, 図 6 のコンク リート電柱のサージインピーダンスを考慮したモデルを用 いた場合, 波形, ピーク值ともによく一致している。避雷 器には, 峻度が $0.3 \sim 0.4 \mu \mathrm{s}$ の電流が流れており, 実測結 果では, 4 号柱および 5 号柱の避雷器の端子間電圧 $V_{p}$ の 初期部分にスパイク状の電圧が観測される。このスパイク 電圧は, 避雷器の急峻波応答特性, ならびに避雷器と分圧 器の回路のインダクタンスのため測定が避雷器に流れる急 峻な電流に影響されることによって生じている。

前者の影響に関しては, 単体試験では, 峻度 $0.5 \mu \mathrm{s}$ の $2.5 \mathrm{kA}$ の電流に対する避雷器の制限電圧は, 峻度 $8 \mu \mathrm{s}$ の 電流に対する制限電圧の約 1.1 倍程度であった。解析に用 いた避雷器モデルではこの急峻応答特性を考慮していな

表 3 避雷器設置時の波形比較（ケース $\mathrm{A}-1$ )

Table 3. Voltage and current waveforms in case A-1.

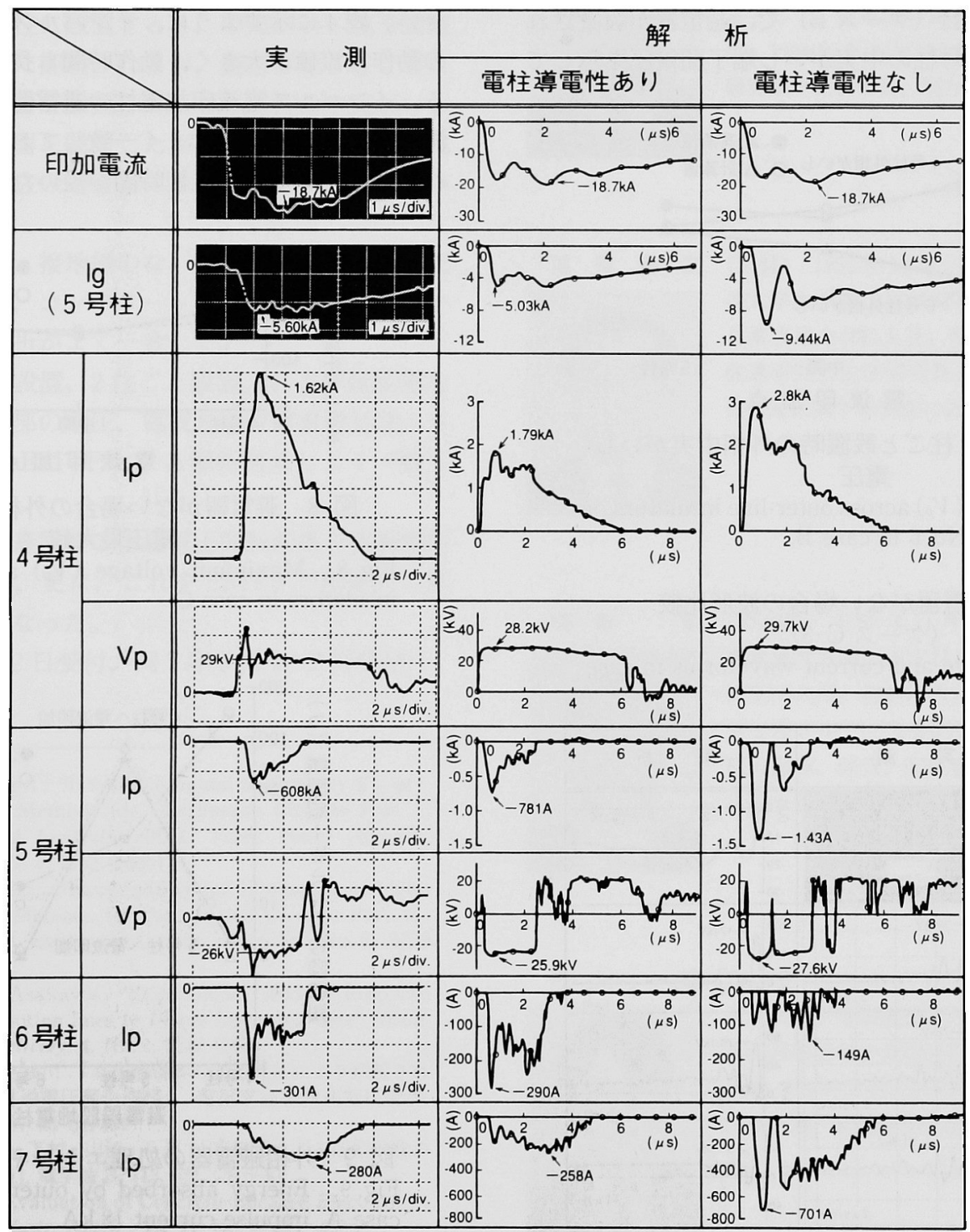


い。後者の測定回路への影響についても単体で試験を行つ た。峻度 $0.5 \mu \mathrm{s}$ の $2.5 \mathrm{kA}$ の電流では峻度 $8 \mu \mathrm{s}$ の場合と 比べて約 20 30\%測定電圧が高くなった。更に, 分圧器 と $\mathrm{E} / \mathrm{O}$ 変換器との間の同軸ケーブルを使った測定回路は, 両端を接地することが避けられなかったため, 電磁誘導の 影響も考えられる。これに対し CT と $\mathrm{E} / \mathrm{O}$ 変換器の間の 電流測定回路は片端接地で, 電磁誘導の影響は少ない。

電圧測定への影響を小さくするには, 分圧器を小さく し, かつ避雷器へ極力近付けることにより避雷器と分圧器 から構成されるループ回路への鎖交磁束を減らす必要があ る。しかし, 今回の実測では, 避雷器を設置しない場合に おいて, 中実がいしの端子間電圧を $300 \mathrm{kV}$ 程度まで測定 する必要があるため, 図 4 に示すように分圧器のサイズが 大きくなり, かつ絶縁距離を確保するため避雷器から離れ て設置する必要があり，上述の対策は困難であった。しか し，スパイク電圧の継続時間が短いため，この電圧波形を 用いて避雷器処理エネルギーを求める場合，大きな誤差は ないと考えられる。

（2）避雷器 2 柱ごと設置の場合 図 7 は避雷器を 2 柱ごとに設置した場合 (ケース B) で, 避雷器が設置され ていない 4 号柱と 6 号柱の中実がいし端子間電圧を示して

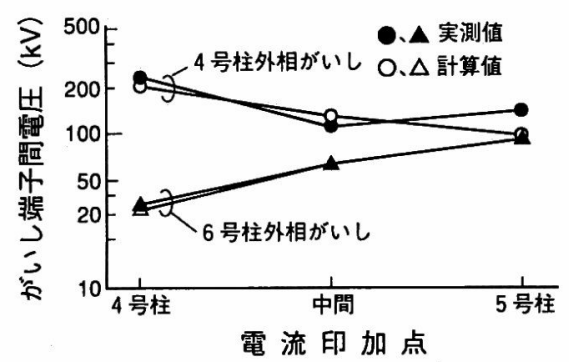

図 7 避雷器 2 柱ごと設置時の外相中実がいし 電圧

Fig. 7. Voltage $\left(V_{p}\right)$ across outer-line insulators on poles No. 4 and No. 6 in case B.

\section{表 4 避雷器がない場合の波形比較}

$$
\text { (ケース C-3) }
$$

Table 4. Voltage and current waveforms in case C-3.

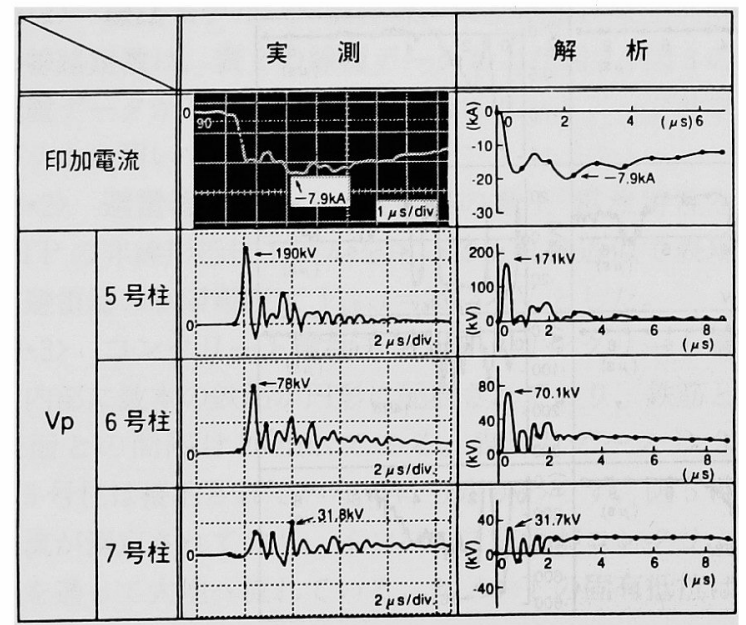

いる。4 号柱に電流を印加した場合に 4 号柱の中実がいし 端子間電圧が最も高くなり, 両側の電柱に避雷器が設置さ れていても避雷器が設置されていないがいしの電圧上昇を 抑制できない。実測結果と解析結果はよく一致している。

（3）避雷器なしの場合＼cjkstart避雷器がない場合（表1の ケース C-3）の実測結果と解析結果の波形の比較を表 4 に 示す。波形，波高值ともによく一致している。中実がいし の $50 \%$ フラッシオーバ電圧は $120 \mathrm{kV}$ であるが, 今回の実 験ではこの值でフラッシオーバしなかった。これは,がい しの $v-t$ 特性によるものと考えられる。図 8 は電流印加 点を変えたときの中実がいし端子間電圧の最大の值を示し たものである。中実がいし両端の電圧は, 実測值と解析値 はよく一致している。

\section{〈4・2〉 避雷器の処理エネルギー}

（1）避雷器全柱設置の場合 全柱に避雷器を設置し た場合の（表 1 のケース A) 各避雷器の処理エネルギー の実測値と解析值の比較を図 9 に示す。インパルス電流の 印加点として 4 号柱または 5 号柱の 2 ケースを試験した が, いずれの場合も雷撃柱の避雷器の処理エネルギーが大 きい。表 4 に示すように, インパルス電流印加柱の避雷器 の動作電流値が大きく, 動作時間も長いことに対応してい る。インパルス電流印加電柱の避雷器の処理エネルギー実 測值と解析值は, 特によく一致して扔り, 実測波形に現わ れたスパイク電圧は継続時間が短いため処理エネルギー値

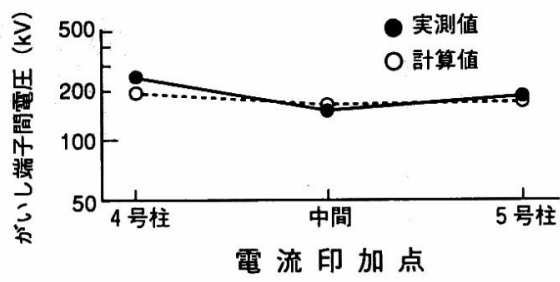

図 8 避雷器がない場合の外相中実がいし 電圧最大值

Fig. 8. Maximum voltage $\left(V_{p}\right)$ across outer-line insulators in case $\mathrm{C}$.

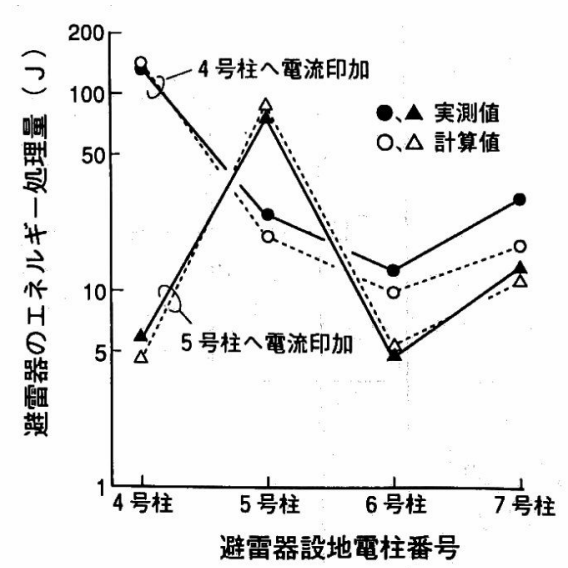

図 9 外相避雷器の処理エネルギー（ケース A)

Fig. 9. Energy absorbed by outer-line arrester in case A, impulse current $18 \mathrm{kA}$. 
への影響が少ない。今回の実測では，設備の制約から印加 電流のピーク值が $18 \mathrm{kA}$ と小さく, かつ波尾長が $11 \mu \mathrm{s}$ と 短いため, 避雷器の処理エネルギー值は $150 \mathrm{~J}$ 程度と小さ い値であった。

（2）避雷器 2 柱ごと設置の場合 2 柱ごとに避雷器 を設置した場合印加電流 $8 \mathrm{kA}$ に対して, 印加柱の避雷器 処理エネルギーは実測值 $13 \mathrm{~J}$ に対し解析値 $11 \mathrm{~J}$ とよく一 致した。

以上のように，実測と解析が一致することから，波高值 が大きく波尾長が長い雷電流に対する避雷器処理エネルギ 一を解析によって求め, 避雷器のエネルギー耐量を評価す ることができる。

\section{5. まと め}

配電用避雷器の雷過電圧抑制効果を評価するために, 実 規模の配電線を用いて, インパルス電流に対する避雷器の 動作電流, 電流, 処理エネルギー, 電柱各部の電圧, 電流 を測定し, 更にEMTPによる解析結果と比較した。これ らの結果の概要は以下のとおり。

（1）避雷器を全柱に設置すると，中実がいし端子間電 圧が避雷器制限電圧に抑制されるが, 避雷器を 2 柱ごとに 設置した場合, 避雷器を設置していない電柱の中実がいし の端子間電圧が避雷器を設置したがいしの端子間電圧に比 べて上昇し, 隣接電柱の避雷器では過電圧を抑制できない ことを確認した。

（2）実験の結果，接地線のない電柱にも雷撃電流が流 れることが観測され, コンクリート電柱の導電性を考慮す ると, 実測結果と解析がよく一致した。

（3）避雷器全柱設置, 2 柱ごと設置, および避雷器な しの場合について各部の電圧, 電流および避雷器処理エネ ルギーの実測波形は EMTP による解析結果とよく一致し た。

これより, 配電用避雷器の雷過電圧抑制効果を実規模配 電線モデルで確認し, 更に, これを EMTP で精度良く解 析することが可能となった。

(平成 6 年 12 月 22 日受付, 同 7 年 5 月 24 日再受付)

$$
\text { 文献 }
$$

(1) Task Force Report: "Investigation and Evaluation of Lightning Protective Methods for Distribution Circuits Part I : Model study and Analysis", IEEE Trans. Power Aparatus Syst., PAS-88, No. 8, 1232 (1969)

(2) Task Force Report: "Investigation and Evaluation of Lightning Protective Methods for Distribution Circuits Part II : Application and Evaluation", ibid., PAS-88, No. 8, 1239 (1969)

(3) S. Yokoyama \& Asakawa: "Experimental study of Response of Power Distribution lines to Direct Lightning Hits", IEEE Trans. Power Delivery, 4, No. 4, 2242 (1989)

（4）大西・今井・横山・浅川:「高圧配電線の雷過電圧により誘起され る低圧配電線の雷過電圧発生様相」, 電気学会放電高電圧研資, ED-87-91; HV-87-38 (昭 62)

（5） 今井・藤原・横山・下村・山岡・石辺：「直撃雷による低配電線の 雷過電圧発生様相」, 電学論 B, 113, 881 (平 5-8)

(6) J.Preminger: "Evaluation of Concrete-Encased Electrodes", IEEE Trans. Industr. Applic., IA-11, No. 6, 664 (1975)

（7）松延・武智・福島：「コンクリート柱の接地効果について」, 昭 54 電気学会全大, 1005

（8）原・山本・藤澤・高畑・横田・横山：「直擊雷による配電設備の被 害様相の分析」, 電気学会電力技術研資, PE-92-23 (平 4)

(9) 藤原・今井・横田・浅川・山岡・下村・石辺：「直揧雷に対する配 電用避雷器の保護効果 (解析) 」, 平 5 電気学会全大, 1426

(10) M. A. Sargent \& M. Darveniza: "Tower Surge Impedance", IEEE Trans. Power Aparatus Syst., PAS-88, No. 5, 193 (1969)

原信 行 (正員) 1965 年 10 月 17 日生。1988 年 3 月千葉

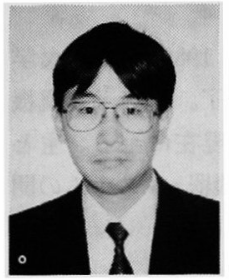
大学工学部電気工学科卒業。同年 4 月東京電力 (株) 入社。現在, 同電力技術研究所流通研究室 に勤務。主として, 配電線の雷害対策に関する 研究に従事。

米山 司 (正員) 1956 年 2 月 19 日生。1981 年日本大学

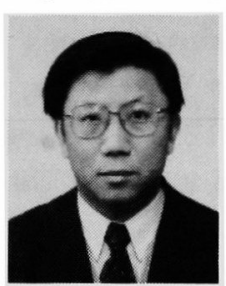
大学院理工学研究科修士課程修了。同年 4 月東 京電力 (株) 入社。同技術研究所流通研究室勤務。 主として, 配電線の雷害対策に関する研究に従 事。1994 年 7 月(財) 日本電気用品試験所出向, 研究部主任研究員, 現在に至る。

濱 田 義 之

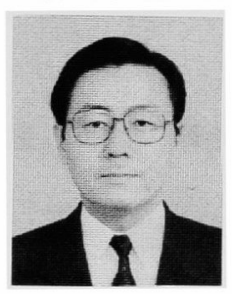

横 田

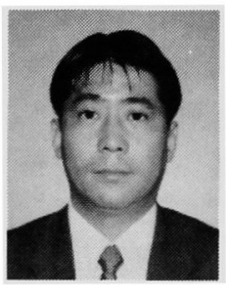

浅 川

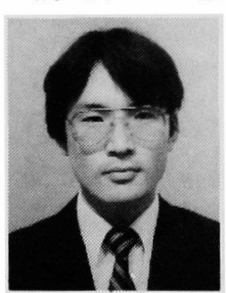

（正員） 1955 年 12 月 21 日生。1982 年 3 月北海 道大学大学院工学研究科修士課程修了。同年 4 月東京電力(株) 入社。現在, 同電力技術研究所 流通研究室主任研究員。主として, 配電線の雷 害対策に関する研究に従事。 
下 村 哲 朗 (正員) 1948 年 4 月 9 日生。1972 年東京大学工 学部電気工学科卒業。同年三菱電機 (株) 入社。 本社（神戸駐在）に勤務, 1987 年同伊丹製作所 勤務, 現在に至る。主として, 電力系統の解析, 電力機器・システムの開発に従事。1992 年電気 学会論文賞受賞。

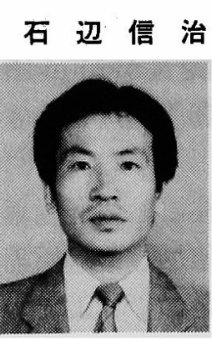

(正員) 1955 年 1 月 9 日生。1978 年九州大学工 学部電気工学科卒業。1 1980 年同大学大学院総合 理工学研究科修士課程修了。同年三菱電機 (株) 入社。伊丹製作所勤務, 現在に至る。避雷器の 開発・設計に従事。1992 年電気学会論文賞受賞。

$\&$

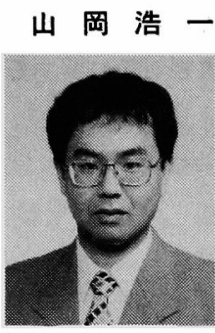

（正員） 1962 年 9 月 12 日生。1989 年神戸大学 理学部理学研究科修士課程修了。同年三菱電機 (株) 入社。伊丹製作所勤務, 現在に至る。主と して, 電力系統の解析, 電力機器・システムの開 発に従事。 